\title{
Environmental concern has to do with the stated purchase behavior of green products at retail?
}

\author{
Sergio Silva Braga Junior ${ }^{1, *}$, Dirceu da Silva ${ }^{2}$, Eduardo Guilherme Satolo ${ }^{1}$, \\ Marcelo Marques Magalhães ${ }^{1}$, Fernando Ferrari Putti ${ }^{1}$, Waleska Reali de Oliveira Braga ${ }^{1}$ \\ ${ }^{1}$ UNESP- Univ. Estadual Paulista, Tupã Campus, Sao Paulo, Brazil \\ ${ }^{2}$ UNINOVE - University Nine de July, Post-GraduationProgramme in Business Administration, Sao Paulo, Brazil

\section{Email address:} \\ sergio@tupa.unesp.br (S. S. B. Junior), dirceuds@gmail.com (D. Silva), eduardo@tupa.unesp.br (E. G.Satolo), \\ marcelo@tupa.unesp.br (M. M. Magalhães), fernandoputti@gmail.com (F. F. Putti), waleskareali@gmail.com (W. R. O. Braga)
}

\section{To cite this article:}

Sergio Silva Braga Junior, Dirceu da Silva, Eduardo Guilherme Satolo, Marcelo Marques Magalhães, Fernando Ferrari Putti1, Waleska Reali de Oliveira Braga. Environmental Concern has to do with the Stated Purchase Behavior of Green Products at Retail? Social Sciences.

Vol. 3, No. 1, 2014, pp. 23-30. doi: 10.11648/j.ss.20140301.15

\begin{abstract}
Does environmental concern influence declared retail purchasing of green products? Current analysis evaluates the influence of environmental concern in people's retail buying behavior of green products. A survey with 811 consumers from Brazil was undertaken on their perception as individuals and the manner they perceive people in society. Results obtained by current analysis show that consumers do not demonstrate a direct relationship between environmental concern and declared retail purchase of green products. The above reinforces the model by Bagozzi (1981) who explains behavior has intent rather than attitude as a precedent. The same behavior may be perceived when subjects place their perception above the behavior of people in society.
\end{abstract}

Keywords: Consumer Behavior, Environmental Concern, Environmental Responsibility, Purchase Declared

\section{Introduction}

Environmental issues are the concern of all and entrepreneurs are increasingly seeking alternatives to decrease or eliminate possible environmental and social negative impacts. Environmental administration has actually become an investment and not a liability (XUEMING \& BHATTACHARYA, 2006).

Since several firms have tried to adapt themselves to these trends, they have incorporated sustainability practices to strategic planning through environmental management and social actions within their communities (BARBIERI, 2007). Such practices are frequently linked to environmental management (CREYER \& ROSS, 1997; SEYFANG \& PAAVOLA, 2008).

Foregrounded on the above context, studies on retail supermarket have become relevant to verify whether consumers perceive the relevance of environmental and social practices. The possibility of evaluating whether firms' environmental and social practices are acknowledged lies in the purchasing and consumption of the final product. The above occurs through the consumers' environmental concern transformed into purchase intention and subsequent buying declaration. The issue that foregrounds current research may be expressed by the following question: Does Environmental Concern affect declared purchase of retailed green products?

Current investigation's general aim is to evaluate whether consumers acknowledge and effectively declare that they buy green products on the retail market. So that the issue in current research could be solved and the above aim complied with, current investigation deals with the behavior of the consumer in two response forms: (1) how do consumers express their attitudes and (2) how do they perceive the attitude of people within society with regard to purchase behavior for green products on the retail market.

Results show that environmental concern is not directly reflected on declared purchase intent for green and organic products on the retail market. However, the perception of respondents is similar in the model construction and is not affected by social desirability, both for the environmental concern and for declared purchase. 


\section{Literature Review}

\subsection{Purchase Attitude and Behavior}

Products in supermarkets are not merely shown to consumers. They are placed to attend to a previously signalized and identified need by marketing so that they could be commercialized in the correct way (KOTLER \& KELLER, 2006).

Market-given stimulus tries to transform purchase intention into purchase attitude and behavior. According to Bagozzi (1981), attitudes will only affect behavior through behavioral intentions, or rather, intentions directly affect behavior and only indirectly attitudes affect consumers' behavior.

According to Ajzen and Fishbein (1977), attitudes are formed by some aspects within the consumers' weltanschauung which represent the evaluation of the product concerned. Attitude measurements are the activities that consumers decide to take in their behavior purchasing in retail supermarkets.

Ajzen (2001) explains that there is a general agreement that attitude represents a quick evaluation of a psychological object caught in attribute dimensions as something good-bad, dangerous-beneficent, pleasant-unpleasant and sympathetic-antipathetic. The above author explains further that attitude facilitates the adaptation of the subjects to the social environment in which they are inserted so that they express and defend their behavior and adequate themselves to it.

So that one may understand how an attitude may be transformed emphatically in purchase behavior, the manner consumers take decisions within the purchase process must be understood. According to Lopes (2010), several authors, with slight variations between them, have shown graphically certain models of decision-taking, divided into stages (HOWARD \& SHETH, 1967; ENGEL, BLACKWELL \& MINIARD, 2005; ALTURAS, 2005).

The above stages show how consumers construct their purchase intentions and the manner intentions become attitudes and buying behavior. It may be observed that, among the stages of models in the process of buying-decision given by the authors above, they provide as a final aim the search for the clients' satisfaction triggered by an issue, a need or a desire signalized or identified by marketing.

The model given by Engel, Blackwell and Miniard (1995) has been much discussed and employed to expose the process of purchase decision made by the consumer. In fact, it is the most complete and detailed in stage description, as Figure 1 shows.

The authors discuss the seven stages of the purchase-decision process and, within each, which are the highest influential aspects within each stage. It is thus possible to evaluate the precise moment the consumer is stimulated by a specific marketing issue or by external factors regardless of the market.

The process starts when consumers perceive the need for a certain product and the satisfaction that the product provides for the consumers' problem (BLACKWELL, MINIARD \&ENGEL, 2005).

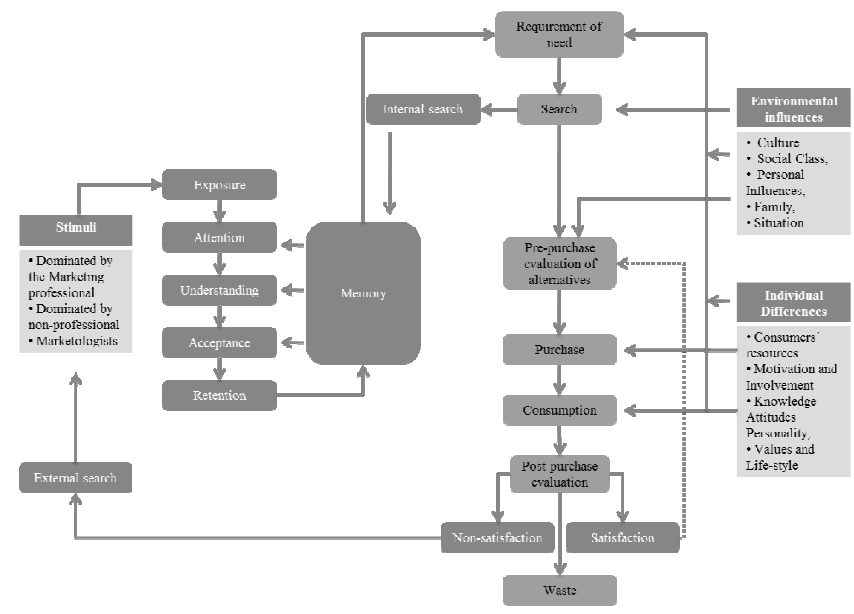

Figure 1.Consumers' decision process.[Source: Blackwell, Miniard\& Engel (2005, p. 86)]

According to Lopes (2010, p.35):

"Stimuli push consumers to seek information on the product. After processing the collected (or received) information, consumers evaluate several alternatives and take an attitude. The installed attitude, coupled to the environmental variables, will determine purchase decision."

So that the perceived need would be solved, a knowledge-bound solution already retained in the memory or collected from external information is sought. Purchase alternatives, which may be simple or sophisticated following consumer-defined evaluation criteria, are thus laid bare.

Consequently, Blackwell, Miniard\& Engel (2005), Alturas (2005), Kotler\& Keller (2006) describe the stages that involve the influences received by consumers in their purchase-decision process in a simplified way (Figure 2)

The first phase, acknowledgement of needs, deals with factors that may affect any time the solution of a problem or the satisfaction of a desire. The first sources of information for the solution of a problem are provided.

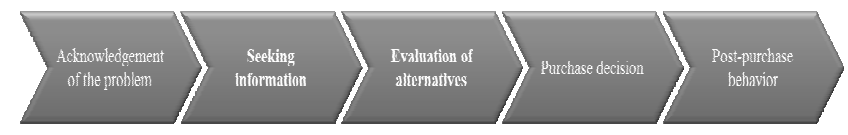

Figure 2. Model of consumers' purchase process. [Source: Adapted from Kotler \& Keller (2006, p. 189)]

Seeking information follows. This consists of the retrieval of knowledge from memory or the collection of information from relatives, friends or the market.

The evaluation of valid alternatives by consumers in their process of information seeking constitutes the third stage. Evaluation criteria and potentially relevant attributes are defined (BLACKWELL, MINIARD \& ENGEL, 2005) and finally determinant attributes for decision-taking are assessed when there is equivalence between evaluation criteria. Purchase and consumption phases come next, mainly characterized by possession and the utilization of the product or service (BLACKWELL, MINIARD \& ENGEL, 2005).

When the process of the consumers' decision-taking is taken into account, the firm must focus on other processes 
prior to purchase, since consumers define in such processes where their money will be applied. Blackwell, Miniard\& Engel (2005) state that influence factors in these processes strongly affect consumers' behavior with regard to their choice for products or services.

Kotler\& Keller (2006) report that beliefs, attitudes and personal, commercial, public and experimental sources, fetched from the consumers' memory, strengthen the processes. Figure 3 shows the information-seeking processes and alternative evaluation with the main influence factors within the consumers' choice process.

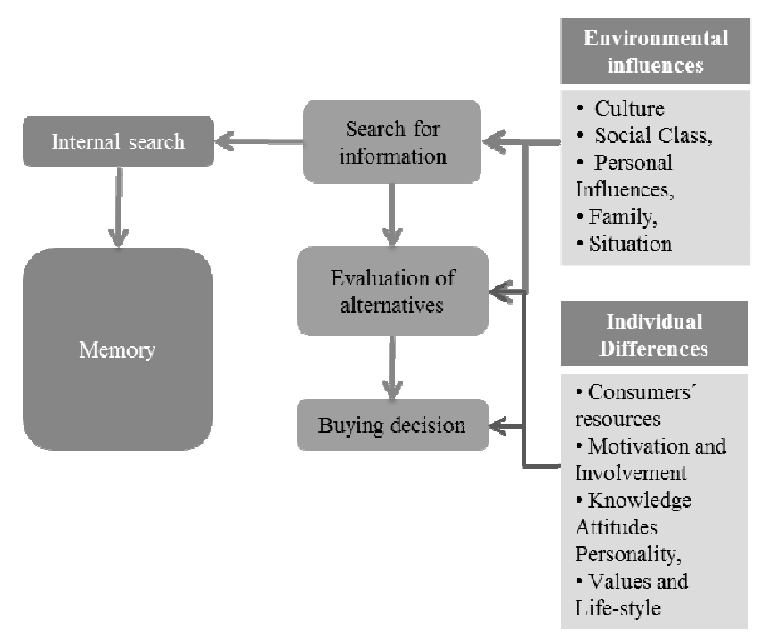

Figure 3. Phases in consumers' decision process and the main influencing factors. [Source: Adapted from Blackwell, Miniard\& Engel (2005, p. 86)]

Knowledge on environmental issues and concerns are currently factors of environmental influence that interferes in purchase behavior for retailed green products. The latter are increasingly gaining ground within the process of information and evaluation of alternatives in Brazil. Consequently, consumers' attitude and perceptions are analyzed in researchers that relate Information Seeking stage with consumers' social and environmental concerns, as provided by Garcia, Silva, Pereira, Rossi \&Minciotti (2008), Bedante\&Slongo (2004) and Seyfang\&Paavola (2008).

The above aspects have been underscored by Lages\& Vargas Neto (2002), Garcia et al. (2008) and Moretti, Silva \& Braga Junior (2010) who insist in stating that the subject's behavior is related to the object of purchase. The authors report that subjects with an ecological-prone relationship with the product or firm are more likely to tend towards the environment and more favorable to firms that show social and environmental responsibility.

The same authors also express the possibility that respondents may be presenting a politically correct behavior within the community and thus establish a research bias which may jeopardize the development of issues linked to the theme.

Politically correct behavior bias is known as social desirability. The subject acquires a behavior, frequently unconscious, within the standards which society defines as correct. Aspects are underscored by Lages\& Vargas Neto (2002), Garcia et al (2008) and Moretti, Silva \& Braga Junior (2010) who demonstrated that the subject's behavior was related to the object of purchase. The above authors reported that subjects with a positive relationship in ecological attitudes towards an ecological attitude with the product and firm were prone to be more favorable to the environment and more reception towards firms that put into practice social and environmental responsibilities. The authors also showed the possibility that respondents were presenting a politically correct behavior within society (social desirability).

\subsection{Social Desirability}

According to Ribas Junior et al. (2004, p. 84), social desirability is "the trend of people participating in psychological research to answer questions biasedly". Respondents are inclined to give answers that they think socially more acceptable and correct even though such replies are against their attitudes, or rather, their true inclinations remain covert if they are not socially acceptable. The term 'social desirability' may also indicate answers given for the sake to pleasing the interviewer (GOUVEIA et al., 2009).

The theory of social desirability explains that politically correct cultural norms and standards affect subjects' answers especially in research that foments self-report, such as personality or psychological content research (GOUVEIA et al., 2009).

A response influence is extant when social and cultural standards affect the subjects' answers. It may be defined as a trend perspective to provide positive answers, or rather, answering positively when questioned, or giving negative answers (always answer negatively), according to Gouveia et al. (2009).

Distortions caused by social desirability may also be related to other variables and subjective characteristics, such as the humor and self-perception. Self-deceit may occur within a research. According to Ribas Junior.et al. (2004), the above occurs when the influence of social desirability is involuntary, or rather, the respondent is not aware of a biased answer. A variation of social desirability is image management that occurs when the respondent manipulates the answer on purpose and thus the personal image transmitted is controlled.

The requirement to know and assess social desirability is due to the fact that the variable may jeopardize the validity and reliability of psychological and behavior research (RIBAS JUNIOR. et al., 2004). Consequently, several social desirability measurement scales have been recently prepared.

According to Poinhos et al. (2008), the Marlowe-Crowne scale is one of the most employed scales to evaluate social desirability indexes. The above scale considers social desirability a trait that evidences the need for social approval and "supposes that a common subject does not always behave within a socially desirable manner" (POINHOS et al, 2008, p.223). The subject who had the direst need of approval will show a greater trend to exhibit socially positive answers (POINHOS et al, 2008). The above-mentioned scale measures the personal inclination to answer questions which are socially desirable even though the answer is untrue. (BARROS, 2005). 
As quoted in Barros (2005), the scale contains 33 items or questions and is based on the concept of types of behavior that, although socially approved, are not common and not so frequent (RIBAS JUNIOR et al., 2008).

According to Poinhos et al. (2008), social desirability corresponds to the trend to transmit a culturally acceptable image and according to social norms, with approval and avoidance of criticism in test situations.

Subjects with high social desirability will be more prone to provide answers that they consider better accepted by society regardless of their status as true or false, denying personal association to socially disapproved opinions or behaviors.

Distortion in social desirability-caused replies may be associated to personal traits (such as humor), conditions and application modes of psychological instruments.

\section{Methodological Procedures}

Current research evaluates consumers' purchase intentions for retailed green products, compares results on their self-evaluation and the manner they observe the attitude of others (or society's). A survey with 811 participants was undertaken to evaluate the following hypotheses:

H1: The subjects' environmental concern is the environmental concern attributed by others.

$\mathrm{H} 2$ :The subjects' declared purchase is the declared purchase attributed by others

H3: The subjects' environmental concern transforms itself into a declared purchase

H4: Environmental concern attributed by others is transformed into declared purchase

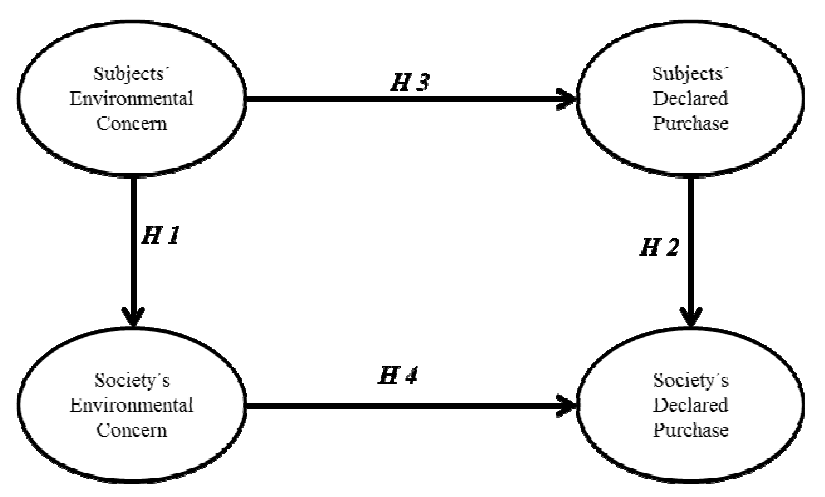

Figure 4.Research hypotheses.

Research survey was undertaken with 811 subjects residing in Brazil, between August and December 2013. Researchers approached the interviewed directly, without any scale interference during the filling so that interference and biased answers could be avoided.

Following recommendations by DeVellis (2003), validated scale contained 17 items on Environmental Concern, 13 on Declared Purchase. Analysis by 10 experts in marketing and environment was undertaken to adjust phrases (evaluation) and to see whether they complied with the construct proposed by the research (phase validity) so that the validation of scale phase in Table 1 to 3 could be assessed. They received the scale to classify the answers within the constructs proposed by research, coupled to the concepts of each construct. An average of 4 questions was classified as not belonging to the research proposal.

Table 1.Scales used in research to evaluate Environmental Concern.

\begin{tabular}{|c|c|}
\hline Lab & Items \\
\hline P_32 & $\begin{array}{l}\text { 1. Firms that damage or disrespect the environment should be } \\
\text { punished. }\end{array}$ \\
\hline P_43 & $\begin{array}{l}\text { 2. Agricultural toxics and dangerous substances in food harm the } \\
\text { environment. }\end{array}$ \\
\hline P_16 & $\begin{array}{l}\text { 3. I switched or did not use anymore products because of eco- } \\
\text { logical motives. }\end{array}$ \\
\hline P_9 & $\begin{array}{l}\text { 4. I understand that organic products do not impact the envi- } \\
\text { ronment }\end{array}$ \\
\hline P_23 & $\begin{array}{l}\text { 5. Environmental declarations demonstrate that the manufacturer } \\
\text { may have concern with the environment. }\end{array}$ \\
\hline P_21 & 6. I am concerned with pollution in my town \\
\hline P_38 & 7. I am worried when I see people dirtying streets and parks \\
\hline P_36 & 8. I separate recyclable wastes from organic residues at home \\
\hline P_4 & 9. Deforesting may place the future of humanity at risk \\
\hline P_27 & 10. I prefer public transport or bike riding \\
\hline P_17 & $\begin{array}{l}\text { 11. I feel that I may help solve the problem of natural resources } \\
\text { by saving water and energy }\end{array}$ \\
\hline P_42 & $\begin{array}{l}\text { 12. I feel I may protect the environment by buying ecologically } \\
\text { correct products }\end{array}$ \\
\hline P_31 & 13. The emission of carbon dioxide damages the atmosphere \\
\hline P_18 & 14. Plastic and paper bags destroy natural resources \\
\hline P_24 & $\begin{array}{l}\text { 15. Plastic and paper bags should be recycled and not deposited } \\
\text { in the environment. }\end{array}$ \\
\hline P_20 & $\begin{array}{l}\text { 16. Home chemical products (detergents and cleaning products) } \\
\text { damage the environment after use }\end{array}$ \\
\hline P 11 & 17. I try to reuse wrappings when possible \\
\hline
\end{tabular}

Table 2. Scales used in research to evaluate Purchase Intention.

\begin{tabular}{cl}
\hline Lab & \multicolumn{1}{c}{ Items } \\
\hline P_14 & $\begin{array}{l}\text { 18. When possible I choose products which cause the least pol- } \\
\text { lution possible. }\end{array}$ \\
P_34 & $\begin{array}{l}\text { 19. I avoid manufactured products that damage or disrespect the } \\
\text { environment. }\end{array}$ \\
P_13 & $\begin{array}{l}\text { 20. I buy food without agricultural toxic products since the } \\
\text { environment is respected. }\end{array}$ \\
P_19 & $\begin{array}{l}\text { 21. I pay a somewhat higher price for products and food free of } \\
\text { chemical substances which damage the environment. }\end{array}$ \\
P_15 & $\begin{array}{l}\text { 22. Difference in price interferes in my intention in buying eco- } \\
\text { logically correct products. }\end{array}$ \\
P_10 & $\begin{array}{l}\text { 23. I may pay more to buy organic products since they do not } \\
\text { impact the environment }\end{array}$ \\
P_33 & $\begin{array}{l}\text { 24. I may prefer products with information on the manufactur- } \\
\text { ers' environmental certificates. }\end{array}$ \\
P_25 & $\begin{array}{l}\text { 25. I verify whether a product that I intend to buy does not } \\
\text { damage the environment or other people }\end{array}$ \\
P_7 & $\begin{array}{l}\text { 26. I am decided to buy concentrated products } \\
\text { 27. I am decided to buy compacted products to reduce gas emis- } \\
\text { sion into the atmosphere }\end{array}$ \\
P_40 & $\begin{array}{l}\text { 28. I am decided to buy products with scanty wrappings to re- } \\
\text { duce the consumption of natural resources } \\
\text { 29. I am decided to avoid buying products with } \\
\text { non-biodegradable wrappings. }\end{array}$ \\
\hline P_5
\end{tabular}




\begin{tabular}{ll}
\hline Lab & \multicolumn{1}{c}{ Items } \\
\hline P_29 & $\begin{array}{l}\text { 30. I am decided to buy home chemical products (detergents and } \\
\text { cleaning products) which are ecologically correct or biodegrad- } \\
\text { able }\end{array}$ \\
P_44 & $\begin{array}{l}\text { 31. I am decided to buy refill products so that the previous } \\
\text { wrapping need not be disposed of }\end{array}$ \\
P_37 & $\begin{array}{l}\text { 32. I am decided to buy some products (currently bought in } \\
\text { smaller sizes) in bigger sizes and with less frequency }\end{array}$ \\
\hline
\end{tabular}

Table 3. Scales used in research to evaluate Declared Intention.

\begin{tabular}{|c|c|}
\hline Lab & Items \\
\hline P_12 & $\begin{array}{l}\text { 33. When I buy a product I always verify whether the manufac- } \\
\text { turing firms damage or disrespect the environment. }\end{array}$ \\
\hline P_41 & $\begin{array}{l}\text { 34. I always buy food without any agricultural toxins since I am } \\
\text { aware that I am preserving the environment. }\end{array}$ \\
\hline P_28 & $\begin{array}{l}\text { 35. I pay more to buy products that promote the protection of the } \\
\text { environment }\end{array}$ \\
\hline P_22 & 36. I buy organic products because they are healthier. \\
\hline P_30 & 37. I pay more to buy organic products since they are healthier. \\
\hline P_3 & $\begin{array}{l}\text { 38. I buy products with environmental certificates since they are } \\
\text { ecologically correct. }\end{array}$ \\
\hline P_2 & $\begin{array}{l}\text { 39. I always choose a product which causes the least damage to } \\
\text { people and to the environment when choosing between two } \\
\text { competitive products. }\end{array}$ \\
\hline P_26 & $\begin{array}{l}\text { 40. I always buy concentrated products since they may save } \\
\text { water and energy }\end{array}$ \\
\hline P_39 & $\begin{array}{l}\text { 41. I buy compacted products to contribute for the decrease in } \\
\text { gas emissions and their transport is easier }\end{array}$ \\
\hline$P_{-} 45$ & 42. I always buy products with the least wrappings possible \\
\hline P_8 & $\begin{array}{l}\text { 43. I always buy ecologically correct or biodegradable home } \\
\text { chemicals (detergents and cleaning products) }\end{array}$ \\
\hline P_35 & $\begin{array}{l}\text { 44. I buy refill products to take advantage of the previous wrap- } \\
\text { ping }\end{array}$ \\
\hline$P_{-} 1$ & $\begin{array}{l}\text { 45. I always buy products with non-traditional packing design } \\
\text { since less solid wastes may be produced. }\end{array}$ \\
\hline
\end{tabular}

Likert-like scale with five agreement-disagreement points was employed in which 1 meant total disagreement and 5 meant total agreement. Research's variables were gender, age, earning and marital status.

For column YOU, participants were asked to give score 1 to 5 for statements to which they disagreed or agreed. For column OTHERS, participants were asked to give score 1 to 5 when it is believed that other people (colleagues, society) would disagree or agree with each statement.

SPSS 15.0 was used for data analysis of frequency tests and Smart PLS 2.0 - M3 was employed to evaluate structural equations modeling (SEM) (RINGLE, WENDE \& WILL, 2005)

SEM was employed as the main method for data analysis. In fact, the model evaluates the causal relationships between the constructs and the subsequent hypotheses test by evaluating past coefficients

Measure model Partial Least Square - Path Modeling (PLS-PM) was employed. When Mardia PK test of adherence to a normal multivariate distribution was undertaken (JÖRESKOG \& SÖBOM, 1993), it was significant $(\mathrm{p}<0.001)$. Consequently, data from matrix variables failed to comply with the desired multivariate distribution

Measurement models for SEM calculation were those with
Free Asymptotic Distribution, or rather, the non-necessity of multivariate normality. Three models may be used: Diagonally Weighted Least Square (DWLS), Weighted Least Square (WLS) and PLS-PM. (JÖRESKOG \& SÖBOM, 1993; HAIR et al., 2009). The first two require extensive samples, or rather, at least, double that obtained in current research. They were disposed of. PLS-PM was an adequate possibility for data analysis. PLS-PM is a quality alternative proven by the international research community in several areas of knowledge (RINGLE, WENDE \& WILL, 2005), with great flexibility in data analysis.

\section{Analysis of Results}

As was discussed for the analysis of the data was used Smart PLS 2.0 M3 software. Departing from the original model with all items of the scale, the model was tested and corrected by removing items that did not have a factor loading above 0.50 (Chin, 1995) and that harm the fit of the model and its statistical validity.

Even so, the averages, standard deviations and coefficients of variation of the responses provided by the individuals of the sample collected for discarded items. Thus, it was found a very low variability (most showed a constant response or disagreement within the same issue without presenting a possible variability analysis).

The $\mathrm{R}^{2}$ evaluates the variables that explain portion of the constructs. Indicates the quality of the fitted model. Values of $0.75,0.50$ and 0.25 are considered significant, moderate and weak, respectively. (Hair et al., 2014). The Average Variance Extracted (AVE) should be greater than 0.50 to satisfy the convergence of the model (Fornell and Larcker, 1981). Already Cronbrach alpha (internal consistency) and Composite Reliability is used to assess whether the sample is free of bias, or if the answers as a whole, are reliable.

The Commonality $\left(\mathrm{f}^{2}\right)$ is evaluated as each construct is "useful" to the model fit. Values of $0.02,0.15$ and 0.35 are considered small, medium and large, respectively and Redundancy $\left(\mathrm{Q}^{2}\right)$ evaluates the accuracy of the fitted model. The evaluation criteria are greater than zero (Hair et al., 2014) values. After those adjustments, the average variance extracted (AVE), composite reliability, Cronbach's alpha and $\mathrm{R} 2$, Commonality $\left(\mathrm{f}^{2}\right)$ and Redundancy $\left(\mathrm{Q}^{2}\right)$ of the constructs were assessed to analyze how the model was measured, as shown in Table 4.

Owing to research data and the relationship between environmental concern and declared purchase, the reflexive model was estimated by structural equations modeling (SEM) in which indicators were construct manifestations (Figure 5).

During the modeling analysis, issues that represented environmental concern and which did not present acceptable minimum adherence in the model's adjustments were removed. These issues reflect an aspect of collective routine behavior purchase. Respondents failed to understand these aspects as factors that interfere in their environmental concern. 
Issues in the construct declared purchase which failed to have the minimum acceptable adherence to the model were also removed. They were actually linked to possible social and environmental attitudes (intention) and to the price of green products. On the other hand, the adjusted items featured biodegradable or compacted products or with scanty wrappings.

Table 4. Quality criteria of model adjustments - SEM specification - Rates of average variance extracted (AVE), composite reliability, $R^{2}$ and Cronbach's Alpha of Constructs.

\begin{tabular}{|c|c|c|c|c|c|c|}
\hline Construct & $\begin{array}{c}\mathbf{A V} \\
\mathbf{E}\end{array}$ & $\begin{array}{l}\text { Com- } \\
\text { posite } \\
\text { relia- } \\
\text { bility }\end{array}$ & $\mathbf{R}^{2}$ & $\begin{array}{l}\text { Cron- } \\
\text { bach's } \\
\text { Alpha }\end{array}$ & $\begin{array}{c}\text { Com } \\
\text { mu- } \\
\text { nality }\end{array}$ & $\begin{array}{c}\text { Re- } \\
\text { dun- } \\
\text { dancy }\end{array}$ \\
\hline $\begin{array}{l}\text { Declared } \\
\text { purchase } \\
\text { Others }\end{array}$ & $\begin{array}{l}0.55 \\
359\end{array}$ & 0.9021 & $\begin{array}{r}0.2 \\
471\end{array}$ & 0.8761 & 0.4013 & $\begin{array}{c}0.127 \\
5\end{array}$ \\
\hline $\begin{array}{l}\text { Declared } \\
\text { purchase Ind }\end{array}$ & $\begin{array}{c}0.50 \\
66\end{array}$ & 0.8601 & $\begin{array}{r}0.6 \\
398\end{array}$ & 0.8046 & 0.3111 & $\begin{array}{c}0.315 \\
6\end{array}$ \\
\hline $\begin{array}{l}\text { Environmental } \\
\text { concern Ind }\end{array}$ & $\begin{array}{c}0.50 \\
35\end{array}$ & 0.8005 & --- & 0.6783 & 0.1908 & $\begin{array}{c}0.190 \\
8\end{array}$ \\
\hline $\begin{array}{l}\text { Environmental } \\
\text { concern Oth- } \\
\text { ers }\end{array}$ & $\begin{array}{c}0.55 \\
05\end{array}$ & 0.8592 & $\begin{array}{r}0.0 \\
785\end{array}$ & 0.7948 & 0.3299 & $\begin{array}{c}0.041 \\
1\end{array}$ \\
\hline $\begin{array}{l}\text { Reference } \\
\text { value }\end{array}$ & $\begin{array}{c}>0.5 \\
0\end{array}$ & $>0.70$ & $\begin{array}{c}\text { See } \\
\text { Tex } \\
t\end{array}$ & $>0.60$ & $\begin{array}{c}\text { Positiv } \\
\text { e }\end{array}$ & $\begin{array}{l}\text { Positi } \\
\text { ve }\end{array}$ \\
\hline
\end{tabular}

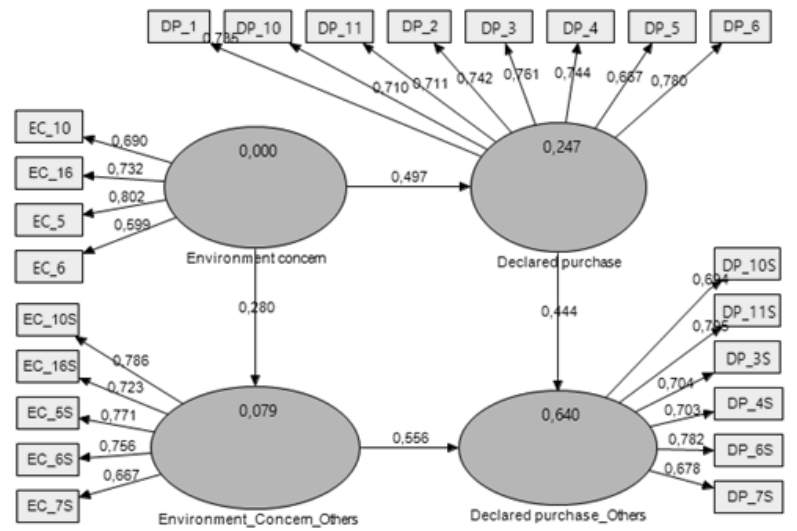

Figure 5. Model adjusted in research. [Note: All structural coefficients were significant $(p<0.05)$. Significance was estimated by bootstrap method with $N=150$ and 1000 replications (RINGLE, WENDE \& WILL, 2005)]

It may be observed that when $\mathrm{R}^{2}$ was evaluated, only Environmental Concern attributed to society (others) was weak in the context of Applied Social Sciences. The above aspect showed that the item composing the construct 'Environmental Concern Others' did not represent substantially the respondents' perception for the construct. It may be stated that the subjects had environmental concern but failed to notice this aspect in the people around them (society).

The above may be corroborated when AVE rates above the references $(>0.50)$ were analyzed, besides the Compound Reliability and Cronbach's Alpha rates, demonstrating well-adjusted model, with quality for interpretation.

Square root of AVEs of each construct was analyzed by Pearson's co-relation coefficients to confirm the discrimi- nating validity of data, as Table 5 shows (CHIN, 1995). The model had discriminating validity when RMS-AVE were higher than Pearson's co-relation coefficients. Table 3 shows RMS-AVE rates higher than co-relations and the existence of the model's discriminating validity.

The model's general quality was calculated by indicator GoF (Goodness-of-Fit) which is the geometric mean of mean $\mathrm{R}^{2}$ and mean AVE (TENENHAUS et al., 2009). Result was given as 0.410 and indicated a well-adjusted model, since, according to the authors, rates over 0.36 were good in the case of Applied Social Sciences (WETZELS et al., 2009).

Table 5. Comparison of AVE versus Co-relationships of Constructs.

\begin{tabular}{ccccc}
\hline & $\begin{array}{c}\text { Purchase } \\
\text { intention } \\
\text { Individual }\end{array}$ & $\begin{array}{c}\text { Pur- } \\
\text { chase } \\
\text { inten- } \\
\text { sion } \\
\text { Others }\end{array}$ & $\begin{array}{c}\text { Environ- } \\
\text { mental } \\
\text { Concern } \\
\text { Individual }\end{array}$ & $\begin{array}{c}\text { Environ- } \\
\text { mental } \\
\text { Concern } \\
\text { Others }\end{array}$ \\
\hline $\begin{array}{c}\text { Declared Purchase } \\
\text { Individual }\end{array}$ & 0.7320806 & & & \\
$\begin{array}{c}\text { Declared Purchase } \\
\text { Others }\end{array}$ & 0.594504 & $\begin{array}{c}0.71174 \\
3\end{array}$ & & \\
$\begin{array}{c}\text { Environmental } \\
\text { concern Individual } \\
\text { Environmental } \\
\text { concern Others }\end{array}$ & 0.497973 & 0.22520 \\
9 & 0.709572 & \\
\hline
\end{tabular}

When the quality of the model's adjustments were confirmed, the inferences on the path coefficients and their rates could be made. Since the model was adjusted, rates may be employed to evaluate the research's hypotheses (Table 6).

Table 6.Evaluation of hypotheses.

\begin{tabular}{lccc}
\hline \multicolumn{1}{c}{ Pathway } & Charge & p-value & Conclusion \\
\hline $\begin{array}{l}\text { Environmental concern Ind } \\
==>\text { Environmental Concern Oth- }\end{array}$ & 0.4442 & 0.0293 & Supported \\
$\begin{array}{l}\text { ers } \\
\begin{array}{l}\text { Declared purchase Ind } \\
==>\text { Declared purchase Others }\end{array}\end{array}$ & 0.4970 & 0.0313 & Supported \\
$\begin{array}{l}\text { Environmental concern Ind } \\
==>\text { Declared purchase Ind }\end{array}$ & 0.2802 & 0.0405 & Supported \\
$\begin{array}{l}\text { Environmental Concern Others } \\
==>\text { Declared Purchase Others }\end{array}$ & 0.5558 & 0.0265 & Supported \\
Reference Value & Positive & $<0,05$ & \\
\hline
\end{tabular}

\section{Conclusions}

The measurement of consumers' perception on social and environmental behavior is increasingly employed since firms are seeking the aggregation of values to their products and are making available retailed green items.

Current research evaluated whether consumers were declaring the purchase of retailed green products. It has been observed that there was no statistically based relationship to justify the link between the two constructs. The subjects' environmental concern did not interfere in their purchase decision with regard to retailed green products.

According to Bagozzi (1981), the subjects' purchase behavior was preceded by the intention of purchasing, which was what really mattered in their decision. When retailed 
green products were concerned, the above relationship was valid and should be the object of other investigations and researches on the same subject. Frequently the decision taken by a subject is not the desired one but that which attended to their needs for the moment. On the other hand, society in which the subjects were inserted failed to produce adaptation conditions and did not require from them attitudes that were not part and parcel of society.

Although Lordelo, Fonseca and Araújo (2000) showed that the results of behavior-linked research were different for different people with different social and economical conditions, the environmental concern in declared purchase did not show changes with categorical variables that formed the social and economical indicator. In fact, most subjects who participated in current research were young people who earned above BRS 4,000.

Since green products are not easily found in great quantities for retail, it may be that most consumers are not really ready to pay for them or at lease did not valorize the firms concerned with environmental issues (GARCIA et al., 2008).

The above aspect may foreground the statements given in hypotheses $\mathrm{H} 1$ and $\mathrm{H} 2$ which present most common items and compose the constructs environmental concern and declared purchase among the subjects' and society's perceptions.

Current analysis was limited since it was a convenience and homogeneous sample, albeit balanced in terms of gender. However, one cannot go beyond these results for the population under analysis. On the other hand, results indicate further knowledge on the theme since it may be observed that environmental concern exists. In fact, people in the sample deemed important the social and environmental attributes. However, it was not reflected wholly in purchase behavior for retailed green products.

Current analysis contributed towards the broadening of the investigation field on the evaluation of purchase intention and declared purchase on environmental concern. Although several debates have been going on the subject, there is only scanty evidence on the success or failure of the initiatives.

The research's contribution for firm management is also accordingly. It should be underscored, however, that the approximation between scholars and market needs upgrading. In fact, little information exchange occurs on research by firms towards development. Great efforts should be employed to link scholarship and market, the two most important information sources on the subject.

\section{Acknowledgements}

The National Council for Scientific and Technological Development $(\mathrm{CNPq})$ for financial support to the survey.

\section{References}

[1] Ajzen, I. (2001). Nature and Operation of Attitudes.Annual Reviews Psychol. v. 52, p. 27-58.

[2] Ajzen, I., \&Fishbein, M. (1977). Attitude-Behavior Relations: A Theoretical Analysis and Review of Empirical Research. PsychologicalBulletin. v. 84, n. 5, p. 888-918.

[3] Alturas, B. (2005). Venda directa: determinantes da aceitação do consumidor. Lisboa, Portugal. ISCTE. Doctoral thesis. Available at http://hdl.handle.net/10071/1157.

[4] Bagozzi, Richard P. (1981). Attitudes, intentions, and behavior: A test of some key hypotheses. Journal of Personality and Social Psychology, Vol 41(4), 607-627. doi: 10.1037/0022-3514.41.4.607

[5] Barbieri, J. C. (2007). Gestão ambiental empresarial: conceitos, modelos e instrumentos. 2.ed. São Paulo: Saraiva.

[6] Barros, R., Moreira, P., \& Oliveira, B. (2005). Influência da desejabilidade social na Estimativa da ingestão alimentar Obtida através de um questionário de Frequência de consumo alimentar. ActaMédPort, v.18, p.241-248.

[7] Bedante, G. N., \& Slongo, L. A. (2004). O Comportamento de Consumo Sustentável e suas Relações com a Consciência Ambiental e a Intenção de Compra de Produtos Ecologicamente Embalados In: Encontro de Marketing da Anpad, I, 2004, Porto Alegre.

[8] Bido, D. S., Silva, D., Souza, C. A., \& Godoy, A. S. (2009). Indicadores Formativos na Modelagem em Equações Estruturais com Estimação via PLS-PM: Como Lidar com a Multicolinearidade Entre Eles? II Encontro de Ensino e Pesquisa em Administração e Contabilidade. EnEPQ 2009. Curitiba, ANPAD.

[9] Bido, D.S., Godoy, A.S., Ferreira, J.F, Moreira, J.,\& Scartezini, V.N. (2011). Examinando a relação entre Aprendizado individual, grupal e organizacional em uma instituição financeira. REAd - Edição 68,v. 17, n. 1, p. 58-86.

[10] Blackwell, R. D., Miniard, P. W., \& Engel, J. F. (2005). Comportamento do consumidor. 9. ed. São Paulo: Pioneira Thomson.

[11] Cardigo, A. C. J. (2008). The adoption of ecological conscious consumer behavior: exploring the association with materialism and voluntary simplicity lifestyles. Dissertation at ISCTE Business School, Lisbo, Portual.

[12] Creyer, E. H., \& Ross Jr., W. T. (1997). The influence of firm behavior on purchase intention: do consumers really care about business ethics? Journal of Consumer Marketing, v. 14, n. 6 , p. 421-432.

[13] DeVellis, R. F. (2003). Scale Development: Theory and Applications. Thousand Oaks: SagePublications.

[14] Elkington, J., Hailes, J., \&Makower, J. (1990). The Green Consumer, New York: Penguin.

[15] Engel, J.F., Blackwell, R.D., \&Miniard, P.W. (1986). Consumer Behavior.5th Edition. Dryden Press, Chicago.

[16] Fornell, C., \&Larcker, D. F. (1981). Evaluating structural equation models with unobservable variables and measurement error. Journal of Marketing Research (JMR), 18(1). 
[17] Garcia, M. N., Silva, D., Pereira, S. R., Rossi, B. G., \& Minciotti, S.A. (2008). Inovação no comportamento do consumidor: recompensa às empresas socioambientalmente responsáveis. RAI - Revista de Administração e Inovação, São Paulo, v. 5, n. 2, p. 73-91.

[18] Gouveia, V. V., Costa, J. M., Araujo, L. B. U., Gouveia, R. S. V., Medeiros, E. D., \& Gonçalves, M. P. (2009). Disposição para perdoar, desejabilidade social e religião: um estudo correlacional. RevistaBioética, 17(2), 297-308

[19] Hair, J. F., Anderson, R. E., Tatham, R. L., \& Black, W. C. (2009). AnáliseMultivariada de Dados. 6a. Ed. Porto Alegre: Bookman.

[20] Harrington, H. J., \& Knight, A. (2001). A implementação da ISO 14000: como atualizar o sistema de gestão ambiental com eficácia. São Paulo: Atlas.

[21] Henseler, J., Ringle, C. M., \&Sinkovics, R. R. (2009). The use of partial least squares path modeling in international marketing. Advances in International Marketing, 20(1), 277-319.

[22] Howard, J., \&Sheth, J.(1969). The Theory of Buyer Behavior.New York: John Wiley.

[23] Irwin, J.R, \& Naylor. R. W. (2009). Ethical Decisions and Response Mode Compatibility: Weighting of Ethical Attributes in Consideration Sets Formed by Excluding Versus Including Product Alternatives, Journal of Marketing Research, 46 (April), 234-46.

[24] Jöreskog, K., \&Sörbom, D. (2003).LISREL 8.54 student edition. Lincolnwood: Scientific Software International.

[25] Kaiser, F. G., Wolfing, S., \& Fuhrer, U. (1999). Environmental Attitude And Ecological Behaviour. Journal of Environmental Psychology. v. 19, p. 1-19.

[26] Kotler, P., \& Keller, K. L. (2006). Administração de Marketing. São Paulo: Editora Atlas.

[27] Lages, N. S., \& Vargas Neto, A. (2002). Mensurando a Consciência Ecológica do Consumidor: Um Estudo Realizado na Cidade de Porto Alegre. Anais do XXVI Encontro da ANPAD, Salvador.

[28] Lopes, E.L. (2010). "Não te conheço bem, mas já gostei de você!". O efeito da marca na negligência da omissão nos diferentes níveis de necessidade cognitiva. Thesis in the Master's and Doctoral Program in Administration. UNINOVE, São Paulo, 2010.

[29] Lordelo, E. R., Fonseca, A. L., \& Araujo, M. L. V. B. (2000). Responsividade do ambiente de desenvolvimento: crenças e práticas como sistema cultural de criação de filhos. Psicologia: Reflexão e Critica, 13(1).

[30] Luo, X., \& Bhattacharya, C.B. (2006). Corporate Social Responsibility, Customer Satisfaction, and Market Value, Journal of Marketing, 70 (October), 1-18.

[31] Miles, M.P., \&Covin, J. G. (2000). Environmental marketing: a source of reputational, competitive and financial advantage.
Journal of Business Etchis. v. 23, n.3, p. 299-311.

[32] Moretti, S. L. A., SILVA, D., \& Braga Junior., S. S. (2010). Fatores de Influência no Consumo "Verde": Um estudo sobre o Comportamento de Compra no Setor Supermercadista. In: XII Encontro Nacional e I Encontro Internacional Sobre Gestão Empresarial e Meio Ambiente, São Paulo.

[33] Morwitz, V. G., Steckel, J. H., \& Gupta, A. (2007). When do purchase intentions predict sales? International Journal of Forecasting. v. 23, p. 347-364.

[34] Poínhos, R., Correia, F., Faneca, M., Ferreira, J., Gonçalves, C., Pinhão, S, \& Medina, J.L. (2008). Desejabilidade Social E Barreiras Ao Cumprimento Da Terapêutica Dietética Em Mulheres Com Excesso De Peso. Acta Med Port, v. 21: 221-228.

[35] Porter, M. E., Kramer, M.R. (2005). A vantagem competitiva da filantropia corporativa, in Ética e Responsabilidade Social nas Empresas; tradução; Afonso Celso da Cunha Serra. Rio de Janeiro: Elsevier.

[36] Pringle, H., \& Thompson, M. (1999). Brand spirit: how cause related marketing builds brands. Chichester: Wiley.

[37] Ribas Junior, R.C., Seidl-de-Moura, M.L., Bornstein, M.H. (2007). Cognições maternas acerca da maternidade e do desenvolvimento humano: Uma contribuição ao estudo da psicologia parental. RevistaBrasileiradoCrescimento e DesenvolvimentoHumano, 17(1):104-113.

[38] Ribas Junior, R.C., \& Seidl-de-Moura, M.L. (2004). Adaptação brasileira da Escala de Desejabilidade Social de Marlowe-Crowne. AvaliaçãoPsicológica, 3(2), pp. 83-92.

[39] Ringle, C.M., Wende, S., \& Will, A. (2010). SmartPLS 2.0 M3 (beta). Germany: Universityof Hamburg, 2005. Available at $<$ http://www.smartpls.de $>$ on 18 Nov 2010.

[40] Schiffman, L. G, \&Kanuk, L. L. (2000). Consumer Behaviour. 9th. New Jersey: Prentice Hall Inc.

[41] Seyfang, G, \&Paavola, J. (2008). Inequality and sustainable consumption: bridging the gaps. Local Environment, Vol. 13 Issue 8, p. 669-684.

[42] Solomon, M.R. (1996). Consumer Behavior, Allyn\& Bacon, London.

[43] Tenenhaus, M., Vinzi, V.E., Chatelin, Y., \&Lauro, C. (2005). PLS Path Modeling. Computational Statistics \& Data Analysis, v.48, p.159-205.

[44] Wetzels, M., Odekerken-Schroder, G., \& Van Oppen, C. (2009). Using PLS path modeling for assessing hierarchical construct models: guidelines and empirical illustration. MIS quarterly, 33(1), 177-195.

[45] Xueming, L., \& Bhattacharya, C. B. (2006). Corporate social responsibility, customer satisfaction, and market value. Journal of Marketing, 70(4), 1-18. 